\title{
THE HEALTH SCHOOL PROGRAMME: A HEALTH PROMOTION STRATEGY IN PRIMARY CARE IN BRAZIL
}

\author{
Maria de Fátima Antero Sousa Machado ${ }^{1}$, Fabiane do Amaral Gubert ${ }^{2}$, \\ Anya Pimentel Gomes Fernandes Vieira Meyer ${ }^{3}$, Yana Paula Coêlho Correia Sampaio ${ }^{4}$, \\ Maria Socorro de Araújo Dias ${ }^{5}$, Ana Mattos Brito de Almeida ${ }^{6}$, Ana Patrícia Pereira Morais ${ }^{7}$, \\ Anamaria Cavalcante e Silva ${ }^{8}$, Jocileide Sales Campos $^{8}$, Maristela Inês Osawa Chagas ${ }^{5}$, \\ Emília Soares Chaves ${ }^{9}$
}

\begin{abstract}
Introduction: the Health School Programme (HSP) should be understood as a permanent development process. In this context, the actions of a policy aimed at children and adolescentsare paramount in the HSP. Objective: to identify and describe the actions developed by the Family Health Group in the HSP, from the National Programme for ImprovingAccess and Quality of Primary Care (PIPCAQ). Methods: this cross-sectional research used secondary data collected fromthe 17,202 groups who joined PIPCAQ in 2012. Results: all regions showed significant results concerning the execution of school activities. the Northern region was the one that performed most school actions $(80.5 \%)$, followed by the Northeast, Midwest, South and Southeast, respectively. However, some items, such as professional training in education and health work need to be streng the ned. Conclusion: HSP in Brazil has mobilised significant actions, even though it has not happened in homogeneously in all Brazilian regions.
\end{abstract}

Keywords: health evaluation, health school programme, primary health care.

\section{INTRODUCTION}

In recent years in Brazil, numerous initiatives and evaluation experiences in primary care have been implemented to achieve improvements in health policies ${ }^{1,2}$.

The National Programme for Improving Access and Quality of Primary Care (PIPCAQ) has, as its main objective, stimulating the expansion of access to, and improvements in,primary health care, in order to allow greater transparency and effectiveness of government actions aimed at primary healthcare.

The PIPCAQ evaluated different health promotions actions carried out in primary care by the Health School Programme (HSP). For the Health Ministry, ${ }^{3}$ the HSP is intended to provide a range of actions for prevention, promotion and attention in the health of children, adolescents and young students, from the basic level of public education, through to the communication between public schools and teams from the Family Health Strategy (FHS), and the realisation of actions directed at students ${ }^{3}$.

The HSP is now major public policy for childhood and adolescence. Among its components are clinical, nutritional and healthy eating promotion, ophthalmologic evaluation, and continuing education actions in health, physical activity, the promotion of a prevention culture in the school context and the inclusion of health education topics in the school political pedagogical project 4 .

Health promotion in the school environment should be understood as a process in permanent development. In order to review and improve actions in the public management of health and professional work processes, and obtain more efficient preventive interventions, these ones have to be realised in places that present the national strategies and programmes in a public health context.

\footnotetext{
1 Universidade Regional do Cariri(URCA) - Crato (CE), Brasil.

2 Universidade Federal do Ceará (UFC) - Fortaleza(CE), Brasil.

3 Fundação Oswaldo Cruz, (FIOCRUZ) Fortaleza (CE), Brasil.

4 Faculdade de Medicina Estácio de Juazeiro do Norte, (Estácio FMJ) - Juazeiro do Norte (CE), Brasil.

5 Universidade Estadual Vale do Acaraú (UVA) - Sobral (CE), Brasil.

6 Escola de Saúde Pública do Ceará (ESPCE) - Fortaleza (CE), Brasil.

7 Universidade Estadual do Ceará (UECE) - Fortaleza (CE), Brasil.

8 Centro Universitário Christus (UNICHRISTUS), Fortaleza (CE), Brasil.

9 Universidade da Integração Internacional da Lusofonia Afro-Brasileira (UNILAB) - Redenção (CE), Brasil.

Regional project coordinators (EC, PI and RN) of the Department of Public Health, Federal University of Rio Grande do Norte/UFRN, Profs. Severina Alice Uchoa, Paulo Medeiro Rocha, Themis Xavier Pinheiro.

Corresponding author: Maria de Fátima Antero Sousa Machado. E-mail: fatimaantero@uol.com.br
}

Suggested citation: Machado MFAS, Gubert FA, Meyer APGFV, Sampaio YPCC, Dias MSA, Almeida AMB et al. The health school programme: a health promotion strategy in primary care in Brazil. Journal of Human Growth and Development. 25(3): 307-312. Doi: http://dx.doi.org/ 10.7322/jhgd.96709

Manuscript submitted Oct 22 2014, accepted for publication Dec 192014. 
The purpose of the study is therefore to identify and describe the actions developed in Brazilby the Family Health Teams (FHT) in the HSP.

\section{METHODS}

This is a cross-sectional study with a quantitative approach, carried out through secondary data provided by the Health Ministry, collected from 17,202 Family Health Teams (FHT) that joined the PIPCAQ in 2012 in Brazil.

The PIPCAQ aims to increase access to, and improve the quality of, primary health care, and is organised in four complementary and robust phases: (1) adherenceand contracting; (2) development; (3) external evaluation, and (4) re-contracting. Data for this study were extracted from the third phase of PIPCAQ and it was conducted by teaching and/or research institutions contracted by the Health Ministry in the period June to October 2012.
The third phase, external evaluation, has been carried out by means of an instrument application that sought to determine the conditions of access to health services and the care quality of participating municipalities and primary care groups. The assessment tool comprised four information gathering modules. Module I asked about the infrastructure, materials, supplies, and medicine conditions of the basic health unit. Module II sought information about the group work process and about the organisation'scare of the user and the actions taken by HSP. Module III checked user satisfaction with, and perception of, the health service, and Module IV represented a set of complementary information to the other modules, answered online by local management.

The results of this study are from Module II, specifically issues relating to health actions carried out within a school. The instrument contained questions relating to the activities of HSP conducted by groups of the FHS and was answered only with 'yes' or 'no', as follows: (Quadro 1).

Quadro 1: Questions used in PIPCAQ for the evaluation of the HSP. Fortaleza,Ceará, Brazil, 2012.

Does the group conduct activities in school?

What types of services are provided by the group?

Does the group record the activities?

Does the group enter information in the Planning, Budget and Finance Integrated System of the Education Ministry: ISEM/HSP?

Has it identified the number of students with the health needs survey?

Does the team plan the activities?

What clinical evaluation activities are carried out (update immunisation schedule; early detection of hypertension; detection of neglected health disorders; anthropometric measurements; ophthalmologic evaluation; auditory evaluation; psychosocial assessment, nutritional assessment and evaluation of oral health)?

Which prevention and health promotion activities are carried out (educational activities on the promotion of nutrition and healthy lifestyles, promotion of corporal practices and physical activity in schools, education for sexual health, reproductive health and STD/AIDS; actions prevention of alcohol, tobacco and other drugs)?

Are training activities for education professionals to work with health education held, as well as discussions with school teachers?

The questionnaire was applied on location, conducted by an interviewer and only one professional group was selected to answer the questions, in a suitable place in the health unit and on a date agreed with the municipal management. The PIPCAQ participation of municipalities and teams was voluntary.

The data were automatically transferred to the national database of the Health Ministry. The study variables were the activities carried out by health professionals in school and areshown in Table 1 . The analyses were performed by comparing the regions. TheStatistical Package for Social Sciences software was used (SPSS Inc., Chicago, USA, version 19.0). Descriptive analyses were performed and categorical variables were analysed using non-parametric tests, Chi-square.

\section{RESULTS}

A significant association between the regions was observed, according the value of $p<0.0001$ to all items of this study.

With regard to the activities that are performedin the schools, all regions showed impressive results, ranging from $80.5 \%$ to $69.4 \%$. The Northern region performed more activities in this scenario, followed by the Northeast, Midwest, South and Southeast, respectively.

Children and adolescent care was observed in the study and the Northeast region achieved $47.7 \%$. This same region showed better indicators when it came to entering information in the Planning, Budget and Finance Integrated Systemof the Ministry of Education (ISEM/HSP) with $29.5 \%$ 
of health groups doing so. The Southeast region only had $12.6 \%$ of the groups entering information into the system.

With regard tothe survey of the number of students and the need for health, $34.9 \%$ of health teams in the Northeast region performed it. The school actions planning item was considered more important than the schoolstudents survey, with $68.5 \%$ of the Northeast region. The Southeast region presented values of $28.2 \%$ and $56.8 \%$ to both items, respectively, considered the lowest among the regions of Brazil. Considering the importance of these two aspects (survey needsand planning of actions), the association was made between these variables, and the result was obtained that the regions who planned their activities also made a survey of health needswitha significance of $p<0.001$.

On the issue of student clinical evaluation, the Midwest region presented at $10.4 \%$, the region where most reported having performed this procedure. The update of the immunisation schedule is highlighted in the Northeast region (55.6\%), followed by the North (52.6\%). Northeastern Brazil also achieved better results in the early detection of hypertension ( $40.4 \%)$, neglected diseases (30.2\%), anthropometric assessment (57.9\%), hearing evaluation (16.0\%), psychosocial assessment $(25.4 \%)$, nutritional assessment $(52.6 \%)$, oral health assessment $(59.6 \%)$, and food security actions and healthy eating (61.1\%). The South region performed best inophthalmic evaluation, with $24.6 \%$.

For promotion and health education activities, the Northern region can be observed as the one that promoted activities in the theme of sexual and reproductive health and sexually transmitted diseases, with $65.1 \%$ and preventing the use of alcohol, tobacco and other drugs at $47.7 \%$.

In the item related to training activities for education professionals to work with health education and have discussions with school teachers, the Northeast region was highlighted, at $23.2 \%$ and $33.2 \%$, respectively. The Southeast region had the lowest percentages in these two items with $13.3 \%$ and $20.1 \%$, respectively. The results are shown in Table 2 below: (Table 1 ).

Table 1: Distribution of activities executed by the Family Health teams that participate in the PIPCAQ, Brazil, 2013.

\begin{tabular}{|c|c|c|c|c|c|c|c|c|c|c|c|c|c|c|c|c|c|c|c|c|c|}
\hline \multirow[b]{2}{*}{ HSP Activities } & \multicolumn{4}{|c|}{$\begin{array}{l}\text { North Region } \\
(n=1045)\end{array}$} & \multicolumn{4}{|c|}{$\begin{array}{l}\text { Northeast Region } \\
\quad(n=5559)\end{array}$} & \multicolumn{4}{|c|}{$\begin{array}{l}\text { Southeast Region } \\
\quad(n=6569)\end{array}$} & \multicolumn{4}{|c|}{$\begin{array}{l}\text { South Region } \\
(n=2920)\end{array}$} & \multicolumn{4}{|c|}{$\begin{array}{l}\text { Central-West Region } \\
\qquad(n=1131)\end{array}$} & \multirow[b]{2}{*}{ p* } \\
\hline & S & $\%$ & $\mathbf{N}$ & $\%$ & $S$ & $\%$ & N & $\%$ & S & $\%$ & N & $\%$ & $S$ & $\%$ & N & $\%$ & S & $\%$ & $\mathbf{N}$ & $\%$ & \\
\hline Executes school activities & & & 196 & 18,8 & 4431 & 79,7 & & 20,2 & 4559 & 69,4 & 2010 & 30,6 & 2240 & 76,7 & 679 & 23,3 & 869 & 76,8 & 236 & 20,1 & 0,001 \\
\hline Attend & & & & & & & & & & & & & 1273 & & & & & & 474 & 3,0 & \\
\hline ISEM/H & & 20,8 & 624 & & 1639 & 29,5 & 792 & & 826 & & & & 428 & & & & & & 77 & 3 & 0,001 \\
\hline Scholars wit & & & 560 & & 1938 & & 493 & & 1855 & & & 41 & 980 & & 12 & & & & & 4 & 0,001 \\
\hline Plane & & & 5 & 14,8 & 3806 & 8,5 & 62 & & 3734 & 56 & & 12,6 & 1866 & & & & & & & 7 & \\
\hline Exe & & & 732 & 70 & 435 & 7,8 & 3996 & & 614 & 9 & 39 & 60 & 299 & 2 & 1941 & & 91 & & 78 & 5,0 & 0,001 \\
\hline te & & & & 27,8 & 3000 & & & & & & & 32,7 & 1267 & & & & & & 24 & 8,0 & \\
\hline & & & 455 & 3,5 & 248 & & & 39,3 & 1583 & & & & 704 & & & & & & 521 & 8,0 & \\
\hline etection & & & & & & & & & & & & & 825 & & & & & & & & \\
\hline Antr & 5 & 0,2 & 316 & 30,2 & 3219 & 9 & 121 & & & 37 & 21 & & 1322 & 45 & 9. & & & & & 8 & 0,001 \\
\hline & & 7 & 614 & 58, & 1155 & 20,8 & 327 & & & 18 & 2 & & 718 & 24 & & & & & & 7 & 0,001 \\
\hline & & 11, & 721 & & 887 & 16,0 & & & & 10 & & & 382 & & & & & & & 4 & 0,001 \\
\hline & & 19 & 641 & 61,3 & 1410 & & 30 & & 11 & & & & 661 & & & & & & & & 0,001 \\
\hline & & 42,7 & 395 & 37,8 & 2922 & 52 & 150 & & & & & & 1157 & & 3 & & & & & 9 & 0,001 \\
\hline Bucal h & 551 & 52,7 & 290 & 27,8 & 3325 & 59,6 & 1106 & 19,9 & & & 1705 & 26,0 & 1623 & & & 21,1 & 584 & 52,7 & 285 & 25,1 & 0,001 \\
\hline tices promotion & 588 & 56,3 & 253 & 24,2 & 3398 & 61,1 & 1033 & 18,6 & 2774 & 42,2 & 1785 & 27,2 & 1421 & 48,7 & 819 & 28,1 & 592 & 53,4 & 277 & 25,5 & \\
\hline $\begin{array}{l}\text { ivity } \\
\text { oductive health }\end{array}$ & 362 & & 479 & & & 33,9 & & & 1599 & & & & 750 & 25,7 & 1490 & 51 & 377 & 34,0 & 492 & 45,0 & 0,001 \\
\hline $\begin{array}{l}\text { and STD/AIDS prevention } \\
\text { Alcohol, tobacco and other }\end{array}$ & 680 & 65,1 & 161 & 15,4 & 3256 & 58,6 & 1175 & & 3038 & 46,2 & 1521 & 23,2 & 1679 & 57,5 & 561 & 19,2 & 662 & 59,7 & 207 & 18,5 & 0,001 \\
\hline $\begin{array}{l}\text { drugs use prevention } \\
\text { Professionals qualification to }\end{array}$ & 491 & 47,0 & 350 & 33,5 & 2399 & 43,7 & 2032 & 36,6 & 2162 & 32,9 & 2397 & 36,5 & 1290 & 44,2 & 950 & 32,5 & 517 & 46,6 & 352 & 31,9 & 0,001 \\
\hline work education/health & 215 & & 626 & 59,9 & 1291 & 23 & 3140 & & 1137 & 17,3 & 3422 & 52, & 646 & 22,1 & 1594 & & 244 & 22,0 & & 57,4 & 0,001 \\
\hline Debate with teachers & 260 & 24,9 & 581 & 55,6 & 1848 & 33,2 & 2583 & 46,5 & 1322 & 20,1 & 3237 & 49,3 & 814 & 27,9 & 1426 & 48,6 & 224 & 20,3 & 645 & 60,0 & 0,001 \\
\hline
\end{tabular}

\section{DISCUSSION}

The HS Pat the national level has mobilised significant actions, even if not evenly across all regions, as shown in the PIPCAQ evaluation results in 2012. Thus, this study contributesan overview of the actions developed in the HSP across the country and can certainly produce a reflection on the range of this programme and its contributions to the improvement in the care of the population. The importance of evaluation studies that allow an overview of reality by the studying the specific case of research is highlighted, as in the case of the HSP in Brazil.
With regard to the promotion and health education actions, the Northern region was the one that most promoted these activities ${ }^{5}$. It is worth mentioning that the Northern and Northeast regions are the ones with more social and economic inequalities than in the rest of the country, with the longest inclusion of Family Strategy activities, and with closer, more effective links.

Difficulties in implementing routine care delivered by health professionals still exist, given that the other community demands of the FHG end up needing a different look. It is necessary here to rethink the HSP from a broader perspective, discussing public policies in each territory, providing 
appropriate environments, and reorienting health services beyond clinical and curative treatments. The health teams seem to hold few clinical actions with schools, since they have a high rate of activity, but still with a fragile routine ${ }^{6}$.

Studies ${ }^{7,8}$, describe the difficulty of establishing a routine in helping adolescents and that this may be linked to the need for some professionals to overcome prejudice before delivering educational programmesin school. Little exposure to the issues of this age group can mean a tendency to view adolescents in a negative and stereotypical manner, embarrassment in dealing with sexuality and violence situations (which may require interdisciplinary interventions), and work overload, making access to learning difficult. These and other situations are factors which can influence this point. For many teenagers, health is still linked to 'absence of disease' and theirsense of invulnerabilityand immortality can justify the indifference and detachment that is observed in the behaviour of adolescents in relation to health services ${ }^{9}$.

The low data entry percentage in ISEM/HSP has hampered the monitoring and evaluation of these actions. Consistent monitoring allows managers andmunicipalities to demarcate their responsibilities and definethe areas of coverage of the FHS teams, contributing to the situational diagnosis based on social determinants in the epidemiological scenario, including the transfer of appropriate incentives for the units.

Studies indicate there is a lack of regularity in the system, a lack of professional training to fill in the spreadsheets and, according to the professionals themselves, the vast number of information systems deployed by the Health Ministry in recent years has demanded too mucheffort from the municipalities. To overcome this situation, caregivers need support in the planning process and decision-making powers with regard to information systems ${ }^{9}$.

The actions planning at school was also evaluated and considered one of the most positive aspects. This shows that health groups are participating in the guidelines proposed by the Health Ministry which states that the execution time of each HSP action is planned by the FHG, taking into account the school year and the school political pedagogical project ${ }^{4}$.

Research conducted in Fortaleza showed the gradual strengthening of the integrationof the education and health sectors, promoting the intersectoral approach proposed by the Unified Health System, despite the challenges such as difficulty maintaining these actions ${ }^{10}$.

The school environment has been recognised as a beneficial setting for promoting health practices, prevention and health education. In this context, it reinforces the prevention of health problems, contributing to the creation of conditions for student learning, and the construction of a social care system, focusing on the promotion of citizenship and human rights. It provides a strengthening of the capacity to cope with vulnerabilities in the health field, which can compromise full school development ${ }^{11}$.Thus, it is within this approach, a health programme at school, inserted and integrated into daily life and school culture, is understood and justified. It is a very important reference space for children and teenagers, who increasingly develop their experiences within significant socialisationspaces and community life ${ }^{11}$.

It was found that the clinical evaluation of schoolswas used for some of the health units in Brazil. To improve care of children and adolescents, realisingthe clinical evaluation is necessary to provide adequate physical spaces $^{12}$ and transport for moving teams, as this becomes an essential resource for maintaining frequent contact between users and staff $^{13}$, and providing innovative educational technologies that streamline and facilitate teaching and learning ${ }^{14}$.

The work with the schoolsregarding health education showed actions directed at promoting sexual and reproductive healthwere the most frequently implemented across the country, with high percentages in all regions. According to the Health Ministry ${ }^{4}$ there has been an increase in the pregnancy rate in girls in recent decades. Also, teenagers have become more exposed to sexually transmitted diseases, such as AIDS, with the inappropriate use of contraceptive methods, coupled with lack of knowledge of, and access to, them. Another important topic discussed at school was the use of alcohol and drugs, and the Northern region was highlighted again. In this sense, the school's partnership with primary care is essential for dialogue, access to information and the reorganisation of practice is the main focus.

With regard to training for operations in the HSP, the study showed that the actions of this nature are not well performed. Ongoing training for professionals who work in schools is essential, and the need to hire professionals from diverse backgrounds, with skills and experience in health promotion actions ${ }^{15}$.

The implications of these findings, to identify the actions taken by HSP, reaffirms the commitment that public policy has to Brazilian children and adolescents, directly impactingtheir quality of life and their health. The transfer of the knowledge between the education and health areas enhances the development of actions that favour the educational dimension of healthcare, the care of oneself, of others and the environment, generating effects on healthy development, the role of education and the community in which they live, allowing them to have options that improve their quality of life ${ }^{16}$.

Thus, to know and handle risk factors and the vulnerabilities of children and adolescents in promoting and protecting health will impact positively on quality of life, on learning conditions and, consequently, on the construction of citizenship ${ }^{11}$.

Issues to be addressed in the school setting, such as sexuality, reveal the importance of developing an environment for health promotion through health education in this context, since it acts as a significant social space where 
teenagersbuild knowledge and promote health in decision-making from their experiences and life expectancies, and trivia about sexuality, among other aspects relating to health ${ }^{17}$.

However, it is important to emphasisethat it is not enough to have open space to promote health.Developing responsibility in the users in these practices, and student participation in the mobilisation, training and development of individual learning and social skills to deal with the processes of health and disease, is essential for implementation of these actions ${ }^{18}$.

Thus, it is necessary that these are consistent with the assumptions of health promotion; however, those actions are still a challenge, given the predominance of curative characteristics and individualistic practices ${ }^{19}$.

For the realisation of educational activities, the involvement of all stakeholders is a unique prerequisitefor the full exercise of health ${ }^{20}$, however in the context involving the HSP, one of the challenges for implementation is the training of education professionals to work with education in health.

Research should be implemented to give visibility to situations such as these. However, while

\section{REFERENCES}

1. Miclos PV, Calvo MCM,Colussi CF. Avaliação do desempenho da atenção primária em saúde através da análise envoltória de dados. RevEletrGestão Saúde. (2015; 6(2): 1749-63.

2. PintoJunior EP, Cavalcante JLM, Sousa RA, Morais APP, Silva MGC. Análise da produção científica sobre avaliação, no contexto da saúde da família, em periódicos brasileiros. Saúde Debate. 2015; 39(104): 268-78. DOI: http:// dx.doi.org/10.1590/0103-110420151040226

3. Ministério da Saúde. Secretaria de Atenção à Saúde. Departamento de Atenção Básica. Instrutivo PSE. Brasília: Ministério da Saúde; 2011.

4. Ministério da Saúde. Secretaria de Atenção à Saúde. Departamento de atenção básica. Cadernos de Atenção Básica. Saúde na escola. Brasília: Ministério da Saúde; 2009.

5. Fausto MCR, Fonseca HS. Rotas de atenção básica no Brasil: experiências do trabalho de campo PMAQ/AB. Rio de Janeiro: Saberes; 2013.

6. Gomes LC. O desafio da intersetorialidade: a experiência do Programa Saúde na Escola (PSE) em Manguinhos, no Município do Rio de Janeiro. Dissertação (Mestrado) - Escola Nacional de Saúde Pública Sergio Arouca. Rio de Janeiro: 2012.

7. Vitalle MSS, Almeida RG, Silva FC. Capacitação na atenção à saúde do adolescente: experiência de ensino. Rev Bras Educ Med. 2010; 34(3): 459-468.

8. Marques JF, Queiroz MV. Cuidado ao adolescente na atenção básica: necessidades dos usuários e sua relação com o serviço. Rev Gaúcha Enferm. 2012; 33(3): 65-72. DOI: http:// dx.doi.org/10.1590/S1983-14472012000 300009 in Brazil scientific production has been increasing significantly, this could increase even more with the proper training of health professionals who work with research in project management ${ }^{21}$.

Investments in permanent health education that contribute to the transformation of professional, educational and health practices, and also to the organisationof services, are essential strategies for improving theseHSP actions. ${ }^{11}$

In this way, it has been shown that the HSP in Brazil has mobilisedsignificant actions, even if it has not performed homogeneously in all Brazilian regions; although all the regions have had elements evaluated by PIPCAQ by presenting the implementation of actions, theregions that have performed more actions are the North and Northeast.

\section{Acknowledgement}

Regional project coordinators (EC, PI and RN) of the Department of Public Health, Federal University of Rio Grande do Norte / UFRN, Profs. Severina Alice Uchoa, Paulo Medeiros Themis Rocha and Xavier Pinheiro.

9. Raposo C. A Política de Atenção Integral à Saúde do Adolescente e Jovem: uma perspectiva de garantia de direito à saúde? RevPauta. Rio de Janeiro: 2009; 6(23): 117-38.

10. Santiago LM, Rodrigues MTP, Oliveira Junior AD, Moreira TMM. Implantaçãoo do Programa Saúde na Escola em Fortaleza-CE: atuação de equipe da Estratégia Saúde da Família. RevBrasEnferm. 2012; 65(6): 1026-9. DOI: http://dx.doi.org/10.1590/S0034-71672012 000600020

11. Ferraz DAS, Nemes MIB. Avaliação da implantação de atividades de prevenção das DST/AIDS na atenção básica: um estudo de caso na Região Metropolitana de São Paulo, Brasil.Cad Saúde Pública. 2009; 25(Suppl2): S240-50. DOI: http://dx.doi.org/10.1590/S0102-311X2 009001400006

12. Baratieri T, Marcon SS. Longitudinalidade no trabalho do enfermeiro: identificando dificuldades e perspectivas de transformação. Texto Contexto Enferm. 2012; 21(3): 549-57. DOI: http://dx.doi.org/10.1590/S0104-07072012 000300009

13. Roecker S, Budó MLD, Marcon SS. Trabalho educativo do enfermeiro na Estratégia Saúde da Família: dificuldades e perspectivas de mudanças. Rev Esc Enferm USP. 2012; 46(3): 641-9. DOI: http://dx.doi.org/10.1590/S008062342012000300016

14. Silva Junior AJ. Programa saúde na escola: limites e possibilidades intersetoriais. Interface. 2014; 18(51): 799. DOI: http://dx.doi.org/ 10.1590/1807-57622014.0583

15. Ferreira IRC, Moysés SJ, França BHS, Carvalho ML, Moysés ST. Percepções de gestores locais sobre a intersetorialidade no Programa Saúde na Escola. Rev Bras Educ. 2014; 19(56): 61-76. 
DOI: http://dx.doi.org/10.1590/S1413-247820 14000100004

16. Bezerra IMP, Machado MFAS, Souza OF, Antão JYFL, Dantas MNL, Reis AOA, et al. Professional activity in the context of health education: a systematic review. J Hum Growth Dev. 2014;
24(3): 255-262. DOI: http://dx.doi.org/ $10.7322 /$ jhdg. 88909

17. Arash HK, Carpentier R. The evolving role of public health in the delivery of health care. J Hum Growth Dev. 2012; 22(3): 396-399. systematic review. J Hum Growth Dev. $2014 ; 24(3): 255-262$.

\section{Resumo}

Introdução: a promoção da saúde no cenário escolar deve ser entendida como um processo em permanente desenvolvimento. Nesse contexto, destacam-se as ações do Programa Saúde na Escola, como política voltada para crianças e adolescentes. Objetivo: identificar e descrever as ações desenvolvidas pelas Equipes de Saúde da Família (ESF) no Programa Saúde na Escola (PSE), participantes do Programa Nacional de Melhoria do Acesso e da Qualidade da Atenção Básica (PMAQ). Método: trata-se de uma pesquisa transversal que utilizou dados secundários coletados junto a 17.202 equipes que aderiram ao PMAQ em 2012. Resultado: todas as regiões apresentaram resultados expressivos acerca da realização de atividades na escola. A região Norte é a que mais executa ações ao escolar $(80,5 \%)$, seguidas das regiões Nordeste, Centro-Oeste, Sul e Sudeste respectivamente. Contudo, alguns itens como a capacitação dos profissionais para trabalhar com educação e saúde precisam ser fortalecidos. Conclusão: o PSE no Brasil tem mobilizado ações relevantes, mesmo que isto não tenha se dado de forma homogênea em todas as regiões brasileiras.

Palavras-chave: avaliação em saúde, saúde escolar, atenção primária à saúde. 